\title{
KELAYAKAN MEDIA PEMBELAJARAN INTERAKTIF MATERI JARINGAN TUMBUHAN DENGAN PENDEKATAN PAIKEM
}

\author{
Ryan Rizki Adhisa ${ }^{1)}$, Dias Aziz Pramudita ${ }^{2)}$, Eric Santoso ${ }^{3)}$ \\ 123) Pendidikan Teknik Informatika Universitas Muhammaidyah Surakarta \\ email : rra980@ums.ac.id ${ }^{1}$, dap207@ums.ac.id ${ }^{2}, \underline{\text { a710160014@student.ums.ac.id }{ }^{2}}$
}

\begin{abstract}
Abstraksi
Media pembelajaran merupakan perantara penyampaian materi pelajaran kepada peserta didik dengan menggunakan alat-alat tertentu agar peserta didik dapat memahami materi dengan cepat. Penelitian ini bertujuan untuk mengembangkan media pembelajaran melalui pendekatan PAIKEM pada materi jaringan tumbuhan berbasis Android dan menguji kelayakannyaMedia dikembangkan dengan software Articulate Storyline 3 dan Website2Apk Builder. Model pengembangan yang digunakan dalam penelitian ini adalah ADDIE (Analysis, Design, Development, Implementation, Evaluation). Hail pengembangan media pembelajaran kemudian diuji kelayakannya. Hasil dari uji coba kepada 2 ahli media memperoleh nilai rata-rata persentase $84 \%$ yang termasuk dalam kategori sangat layak menggunakan skala Liekert. Selain itu hasil rata-rata pengujian validitas isi dengan Aiken's V didapati koefisien V sebesar 0,79 yang dinyatakan valid. Sedangkan hasil uji coba kepada 2 ahli materi memperoleh nilai rata-rata persentase $81,62 \%$ yang termasuk dalam kategori sangat layak dengan hasil ratarata koefisien $V$ sebesar 0,753 dinyatakan valid. Koefisien V dari hasil pengujian implementasi aspek PAIKEM pada media oleh ahli materi sebesar 0,766 juga dinyatakan valid. Hasil uji kelayakan kepada 5 memperoleh nilai rata-rata persentase 86,5\%; termasuk dalam kategori sangat layak dengan rata-rata koefisien V sebesar 0,86 dan koefisien $V$ untuk memvalidasi implementasi PAIKEM pada media sebesar 0,77 sehingga keduanya dinyatakan valid.
\end{abstract}

Kata Kunci : android, media pembelajaran, PAIKEM

\begin{abstract}
Learning media are an intermediary for delivering subject matter to students by using certain tools so that students can understand the learning subject quickly. This study aims to develop learning media through the PAIKEM approach on Android-based Plant Tissue material and test its feasibility. The media were developed using Articulate Storyline 3 and Website2Apk Builder software. The development model used in this research is ADDIE (Analysis, Design, Development, Implementation, Evaluation). The results of the development of learning media are then tested for feasibility. The results of the trial to 2 media experts obtained an average percentage value of $84 \%$, which was included in the very feasible category using the Liekert scale. In addition, the results of the average content validity test with Aiken's $V$ found a V coefficient of 0.79 which was declared valid. While the results of the trial to 2 material experts obtained an average percentage value of $81.62 \%$, which was included in the very feasible category with an average coefficient $V$ of 0.753 which was declared valid. The coefficient $V$ from the results of testing the implementation of the PAIKEM aspect on the media by material experts of 0.766 is also declared valid. The results of the feasibility test to 5 obtained an average percentage value of $86.5 \%$; included in the very feasible category with an average coefficient $V$ of 0.86 and a coefficient of $V$ to validate the implementation of PAIKEM on the media of 0.77 so that both are declared valid.
\end{abstract}

Keywords : android, learning media, PAIKEM 


\section{PENDAHULUAN}

Pembelajaran yang efektif adalah pembelajaran yang dapat menarik minat peseta didik dalam mempelajari suatu hal lebih dalam dengan efektif dan efisien. Efektif disini berarti peserta didik dapat memahami semua pokok bahasan yang diangkat, sedangkan efisien berarti siswa dapat memahami keseluruhan pokok bahasan tersebut dengan paparan seminimal mungkin [1].

Dari hasil observasi yang dilakukan peniliti di MTSN 2 Surakarta pada bulan September tahun 2019, dalam proses pembelajaran, masih banyak guru yang menggunakan metode konvensional atau metode ceramah. Penyampaian materi menggunakan metode ceramah dengan media papan tulis menyebabkan peserta didik kurang tertarik dengan materi yang disampaikan menyebabkan waktu pelajaran yang terbuang dan kegaduhan peserta didik dalam proses pembelajaran. Agar siswa memahami materi yang disampaikan, guru perlu mengulang berkalikali penjelasan yang disampaikan. Guru di sekolah tersebut masih menggunakan media LKS dan buku paket dalam proses belajar, sehingga minat siswa dalam belajar semakin rendah. Dibuktikan dengan siswa yang hanya mencatat dan mendengarkan apa yang di sampaikan oleh guru, namun saat guru bertanya, siswa tidak dapat menjawab dengan benar, menandakan pemahaman mereka terhadap materi masih rendah.

Untuk mensiasati permasalahan tersebut, sebuah strategi pembelajaran tertentu dapat diterapkan [2], [3]. Salah satu strategi pembelajaran yang dapat diterapkan adalah PAIKEM. Strategi pembelajaran PAIKEM merupakan singkatan dari Pembelajaran Aktif, Inovatif, Kreatif, Efektif, dan Menyenangkan. Strategi pembelajaran ini menggambarkan keseluruhan proses belajar mengajar yang berlangsung secara efektif dan menyenangkan dengan melibatkan peserta didik untuk berpartisipasi secara aktif selama proses pembelajaran [4]. Dalam beberapa penelitian terdahulu telah digunakan strategi PAIKEM dalam pembelajaran di sekolah dengan hasil yang dapat meningkatkan minat belajar siswa maupun pemahaman siswa dalam bidang mata pelajaran IPA [1], [5], [6]. Penerapan strategi PAIKEM pada penelitian tersebut sebatas dalam kegiatan belajar mengajar di kelas dengan berbantukan media fisik. Padahal, jika digunakan sebuah media pembelajaran interaktif digital seperti aplikasi mobile, terbukti dapat semakin meningkatkan minat belajar dari peserta didik [7].

Berdasarkan uraian diatas, dalam penelitian ini akan dikembangkan sebuah aplikasi media pembelajaran untuk pembelajaran dengan strategi PAIKEM untuk materi Jaringan Tumbuhan di kelas VIII. Media ini dibuat menggunakan Articulate Storyline 3 dengan hasil akhir berupa aplikasi berbasis aplikasi mobile. Aplikasi ini diharapkan layak untuk digunakan sebagai media pembelajaran interaktif yang akan diterapkan pada siswa jenjang MTS/SMP.

\section{METODE PENELITIAN}

Model pengembangan yang digunakan dalam penelitian ini adalah model ADDIE. Model ADDIE yaitu singkatan Analysis, design, development, implementation, evaluation adalah pendekatan umum secara luas digunakan dalam pengembangan kursus instruksional, pendekatan ini memberikan tahapan yang berguna dan didefinisikan dengan jelas untuk implementasi instruksi yang efektif [8] Alasan digunakannya model pengembangan ADDIE, dikarenakan pada model pengembangan ini memiliki keunggulan yaitu dilihat dari prosedur kerjanya yang spesifik dengan acuan untuk pengembangan bahan ajar/media pembelajaran sehingga cocok untuk pengembangan media yang diusulkan[9].

Pada penelitian oleh Parsazadeh telah dirancang sebuah Aplikasi Pembelajaran Seluler Kooperatif dan Interaktif (CIMLA), pada penelitian ini digunakan model desain sistem instruksional (ADDIE) dalam lima tahap: analisis, desain, pengembangan, implementasi, dan evaluasi. Pada Error! Reference source not found. ditunjukkan ilustrasi konsep alur ADDIE yang akan digunakan dalam penelitian ini [10]. Dikarenakan kondisi Pandemi Covid-19, pada penelitian ini tidak dilakukan diseminasi produk secara massal hingga tahap 4 dan 5 dari model ADDIE yang digunakan, sehingga langkah akhir adalah uji kelayakan untuk mencari tahu apakah media yang dikembangkan layak digunakan atau tidak. 


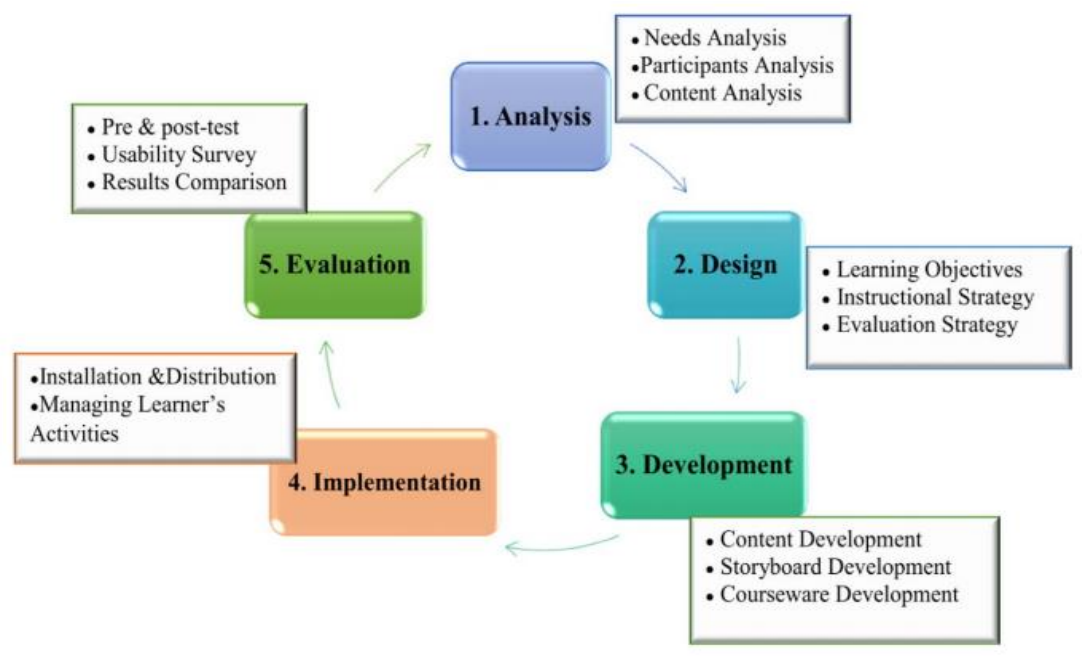

Gambar 1. Langkah-langkah model pengembangan ADDIE [10].

\section{HASIL DAN PEMBAHASAN (12pt, Bold, Capital)}

Sesuai dengan yang telah dijelaskan pada bagian sebelumnya, berikut adalah langkah-langkah yang ditempuh dalam penelitian ini sesuai dengan model pengembangan ADDIE:

\section{Analysis}

Pada tahap ini dilakukan wawancara dengan 2 orang guru mata pelajaran IPA di MTS N 2 Surakarta dan didapati kebutuhan user dengan spesifikasi aplikasi yang dikembangkan ditunjukkan pada Tabel 1.

Tabel 1. Spesifikasi Kebutuhan User

\begin{tabular}{|c|l|l|}
\hline No & \multicolumn{1}{|c|}{ Fitur yang Diperlukan } & \multicolumn{1}{c|}{ Keterangan } \\
\hline 1 & Berbasis aplikasi Android & $\begin{array}{l}\text { Guru menginginkan aplikasi agar dapat dibuka di } \\
\text { mana saja dan mayoritas smartphone siswa adalah } \\
\text { berbasis Android }\end{array}$ \\
\hline 2 & Terdapat Menu KI \& KD & $\begin{array}{l}\text { Diperlukan untuk mengetahui Kompetensi Inti dan } \\
\text { Kompetensi Dasar pembelajaran. }\end{array}$ \\
\hline 3 & $\begin{array}{l}\text { Terdapat Menu Materi } \\
\text { Pembelajaran }\end{array}$ & $\begin{array}{l}\text { Guru memerlukan media pembelajaran dengan materi } \\
\text { Struktur dan Fungsi Akar, Struktur dan Fungsi } \\
\text { Batang, Struktur dan Fungsi Daun. }\end{array}$ \\
\hline 4 & Terdapat Menu Quiz & Diperlukan untuk latihan mengerjakan soal. \\
\hline 5 & Terdapat Menu Hasil Belajar & Diperlukan untuk evaluasi siswa. \\
\hline 6 & Terdapat Video Pembelajaran & $\begin{array}{l}\text { Menurut Guru pengampu, penyampaian materi IPA } \\
\text { dapat lebih efektif jika disampaikan dengan video } \\
\text { pembelajaran. }\end{array}$ \\
\hline
\end{tabular}

Berdasarkan sepesifikasi media yang didapati, kebutuhan hardware dan software yang mendukung dalam proses pengembangan media pembelajaran ini yaitu : Laptop dengan sistem operasi Windows 10, Software Articulate Storyline 3, dan Software Web2Apk Builder.

\section{Design}

Pada tahap ini dibuat desain dari media yang akan dikembangkan salah satunya dengan Use Case Diagram, yang fungsinya untuk menampilkan gambaran skenario dari interaksi yang dilakukan pengguna terhadap aplikasi media pembelajaran, ditunjukkan pada Gambar 2. 


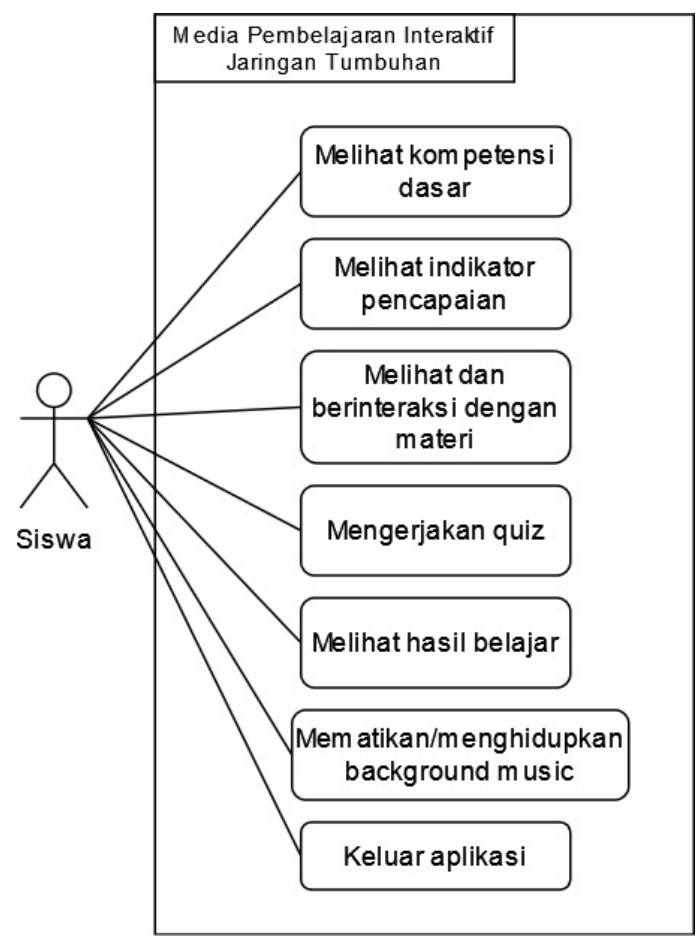

Gambar 2. Use case diagram media pembelajaran yang akan dikembangkan.

Pembuatan Activity diagram menampilkan menu utama, pengguna membuka kemudian menjalankan aplikasi media pembelajaran operasi hitung penjumlahan dan pengurangan, lalu sistem akan merespom dengan menampilkan tampilan menu utama berupa menu materi, video pembelajaran, kuis, pengaturan, petunjuk dan keluar. Activity diagram menampilkan menu utama ada pada Gambar 3.

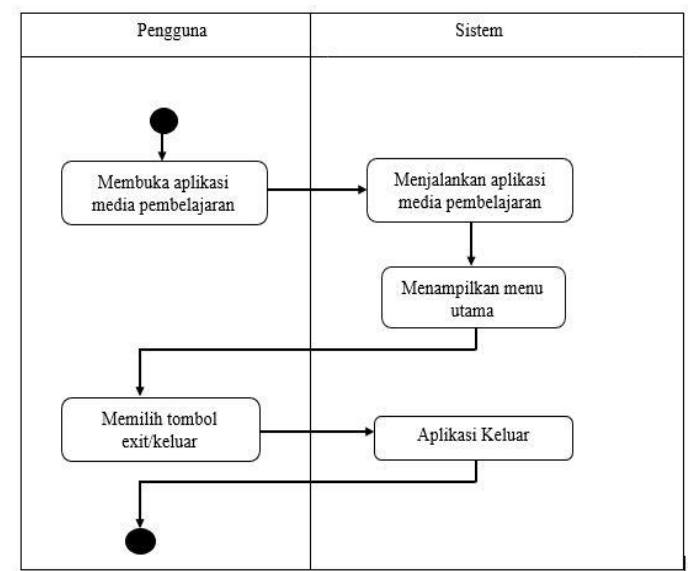

Gambar 3. Activity Diagram Menu Utama

Selanjutnya dibuat wireframe dari sistem. Tujuannya adalah untuk menggambarkan layout dari system yang nantinya akan direalisasikan saat proses development. Contoh diagram wireframe yang dibuat untuk menu utama aplikasi ditunjukkan pada Gambar 4. 


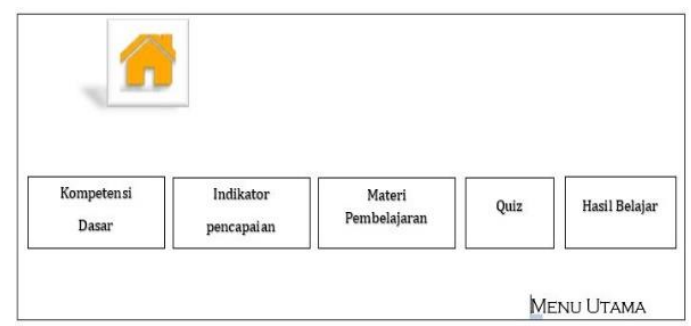

Gambar 4. Wireframe dari Menu Utama Aplikasi yang Akan Dibuat.

\section{Development}

Pada bagian ini dibahas proses pembuatan media yang diusulkan beserta hasil akhirnya. Setelah itu dilakukan pengujian fungsionalitas dan pengujian kelayakan media yang dibuat. Berikut adalah tahapan pengembangan media yang dilakukan:

a. Pembuatan Media Pembelajaran Menggunakan Articulate Storyline 3 dan Website 2 APK Builder.

Pertama dibuat project baru pada aplikasi Articulate Storyline 3. Kemudian dibuat konten secara bertahap dimulai dari halaman utama media. Pada Gambar 5 merupakan tampilan membuat button menu utama. Untuk membuat button menu dibuat menggunakan tools insert lalu pilih retacle kemudia di duplikat dengan cara tekan tombol Ctrl+D, untuk memasukkan teks pada bagian kotak tombol tersebut dengan cara klik kanan pada kotak lalu pilih "Add Text".

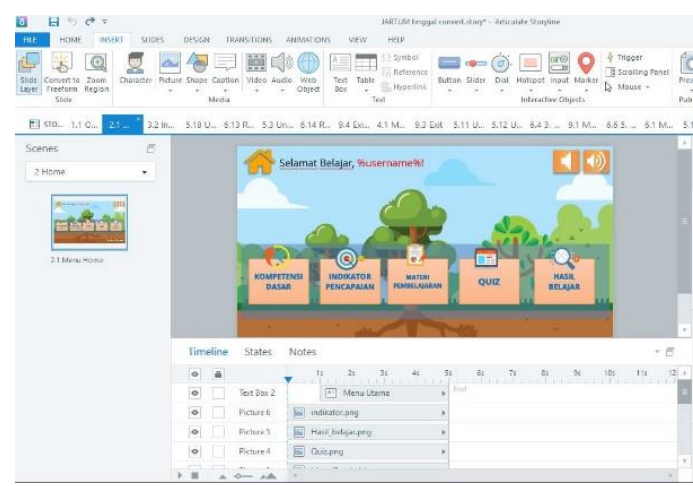

Gambar 5. Membuat Menu Button.

Setelah semua aset media telah dibuat, kemudian dilakukan proses implementasi animasi. Pada Gambar 6 ditunjukkan beberapa tools yang digunakan dalam proses editing yaitu tool Timeline digunakan untuk mengatur animasinya kapan dan berapa detik untuk muncul, sedangkan tool States digunakan untuk editing di saat anak panah meng klik 5 button tersebut akan muncul efek animasinya.

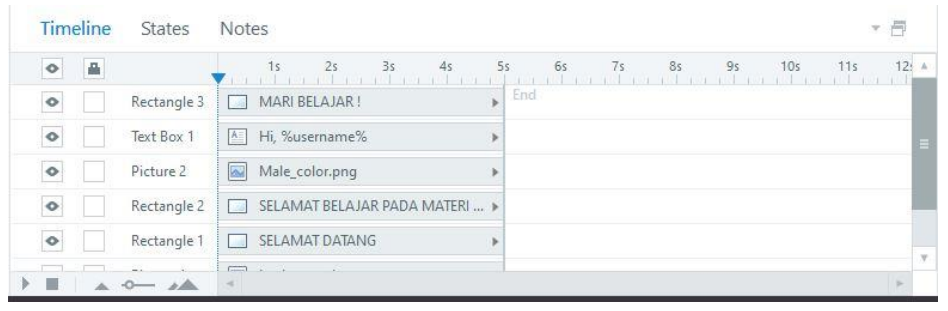

Gambar 6. Tools Editing Animasi.

b. Hasil Pengembangan Media Pembelajaran

Berikut merupakan hasil dari pembuatan produk media pembelajaran interaktif yang sesuai dengan rancangan yang telah dibuat oleh peneliti. 


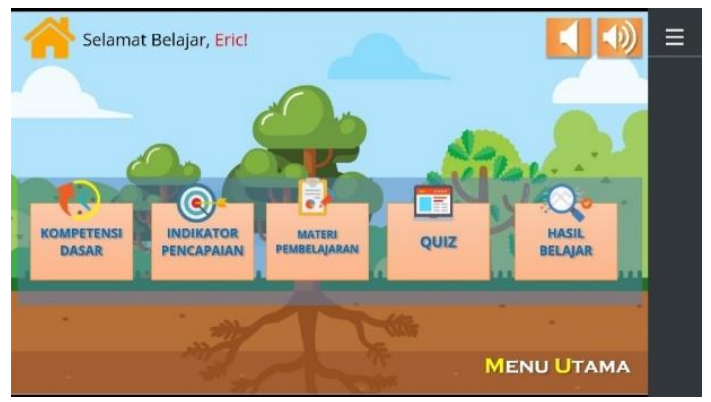

Gambar 7. Tampilan Menu Utama Media.

Gambar 7 merupakan tampilan menu utama media yang menampilkan tombol home, tombol sound on/off dan beberapa sub-menu di antaranya kompetensi dasar, indikator pencapaian, materi pembelajaran, quiz/latihan soal, dan hasil belajar. Pada tampilan menu utama ini merupakan implementasi dari elemen Menyenangkan pada pendekatan PAIKEM, karena media didesain dengan tema ceria dengan ikon-ikon yang sesuai. Selain itu juga diputar musik dengan tema ceria dalam halaman home [11].

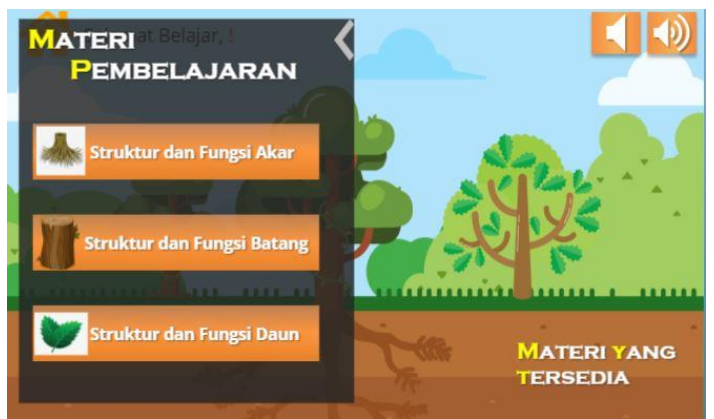

Gambar 8. Tampilan Menu Materi.

Gambar 8 merupakan tampilan menu utama materi yang berisikan 3 materi yaitu struktur dan fungsi akar, struktur dan fungsi batang, struktur dan fungsi daun serta ada 2 video di bagian struktur dan fungsi daun, tampilan ini juga berisikan tombol sound on/off, tombol home serta tombol anah panah ke kiri untuk menutup 3 materi tersebut untuk kembali ke menu utama. Tampilan disini menerapkan elemen-elemen PAIKEM di desainya yaitu elemen Aktif, Efektif dan Menyenangkan, karena materi secara lengkap ditampilkan dalam beberapa bagian yang menuntut siswa untuk berinteraksi dengan media dengan tampilan dan warna yang cerah. [12].

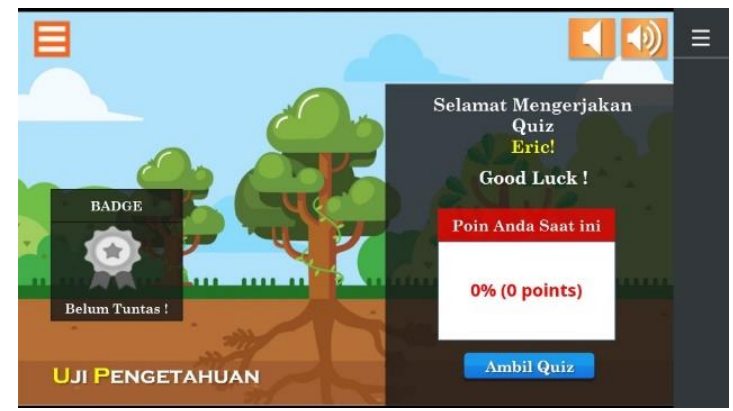

Gambar 9. Tampilan Menu Awal Quiz.

Gambar 9 merupakan tampilan awal quiz yang berisikan tombol sound on/off, tampilan ketuntasan yang jika nilainya melebihi KKM nanti tombol ketuntasan tersebut akan berwarna hijau, ada tampilan poin juga. Jika ingin memulai quiz langsung saja klik tombol "Ambil Quiz" dan akan masuk ke menu utama quiz terdiri dari 10 soal pilihan ganda. Tampilan ini merupakan implementasi elemen Aktif, Inovatif, dan Menyenangkan pada pendekatan PAIKEM karena dengan pendekatan gamifikasi yang dilengkapi dengan timer dan skor, siswa akan semakin kompetitif dalam menjawab soal yang ada [13].

\section{c. Pengujian Blackbox}

Pengujian Blackbox ditujukan untuk menguji fungsionalitas dari aplikasi yang dikembangkan [14]. Pengujian dilakukan dengan membut skenario pengujian dan hasil yang diharapkan dari skenario tersebut. Jika hasil sesuai dengan apa yang diharapkan maka pengujian dikategorikan berhasil. Pengujian dilakukan oleh 5 orang responden 
yang dipilih secara acak dari siswa kelas X MTSN 2 Surakarta. Pada Tabel 2 dapat dilihat bahwa dari 14 skenario pengujian yang ada didapati dari kelima responden memiliki tingkat keberhasilan $100 \%$, yang artinya semua fitur dan tombol pada aplikasi berfungsi dengan baik.

Tabel 2. Hasil pengujian Blackbox.

\section{d. Proses Instalasi Aplikasi.}

\begin{tabular}{|c|c|c|}
\hline Penguji & Berhasil & Gagal \\
\hline 1 & 14 & 0 \\
\hline 2 & 14 & 0 \\
\hline 3 & 14 & 0 \\
\hline 4 & 14 & 0 \\
\hline 5 & 14 & 0 \\
\hline Rata-rata & $100 \%$ & $0 \%$ \\
\hline
\end{tabular}

Proses pemasangan aplikasi ilakukan dengan cara mengkonversi media yang telah dikembangkan dengan Articulate Storyline 3 dalam bentuk ekstensi .apk menggunakan aplikasi Website2ApkBuilder. Gambar 10 merupakan tampilan aplikasi hasil eksport yang akan dipasang pada perangkat Android, sedangkan pada Gambar 11 ditunjukkan jendela konfirmasi pemasangan aplikasi. Gambar 12 merupakan tampilan dimana aplikasi tersebut sudah terpasang dan siap digunakan.

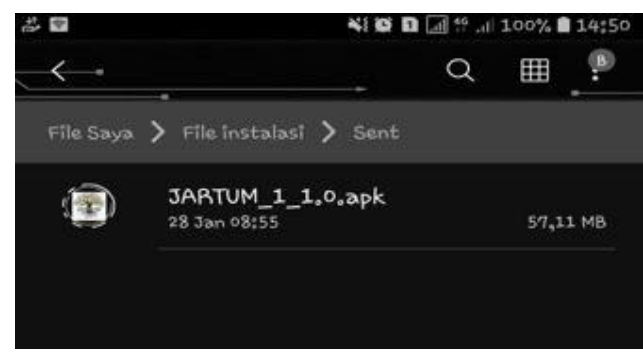

Gambar 10. Hasil Export Aplikasi yang Dikembangkan dalam Format Aplikasi Android.

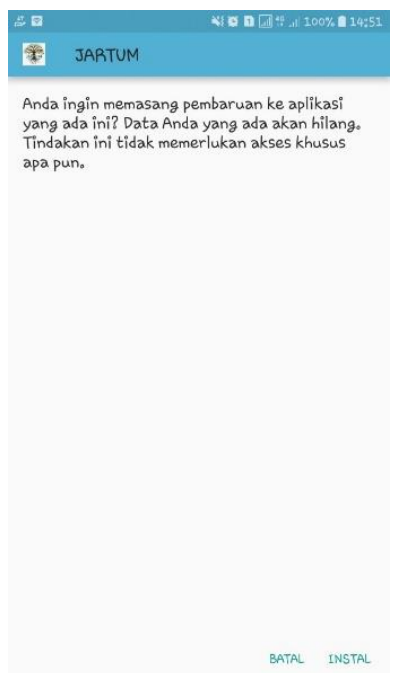

Gambar 11. Proses Pemasangan Aplikasi pada Perangkat Android. 


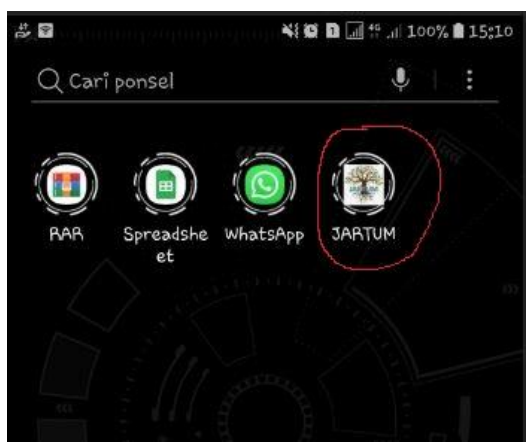

Gambar 12. Aplikasi Telah Berhasil Dipasang dan Tampil Pada Halaman Menu.

e. Uji Kelayakan Media yang Dikembangkan.

Pengujian kelayakan dari media yang dikembangkan dilakukan dengan memberikan angket kepada 2 ahli media, 2 ahli materi, dan 5 orang siswa. Instrumen yang digunakan adalah seperti yang digunakan pada [15] dengan tambahan pertanyaan untuk memvalidasi penerapan strategi PAIKEM dalam elemen desain media yang dikembangkan. Hasil dari pengisian angket tersebut kemudian dikategorikan kedalam 5 skala kelayakan menggunakan perhitungan presentase interpretasi menggunakan skala Liekert [15]. Pengujian validitas isi juga dilakukan menggunakan formula Aiken's V [16] dengan formula yang ditunjukkan pada (1) bertujuan untuk memvalidasi instrumen yang digunakan.

$$
\text { Nilai rata }- \text { rata }=\frac{\text { Jumlah nilai } V}{\text { banyak } \text { item }}(1)
$$

Hasil dari perhitungan angket kelayakan ahli media ditunjukkan pada Tabel 3 dengan hasil rata-rata perhitungan penilaian kelayakan yang masuk dalam kategori kualitas "Sangat Layak". Untuk ahli materi ditunjukkan pada Tabel 4 dengan hasil perhitungan rata-rata penilaian kelayakan yang masuk dalam kategori kualitas "Sangat Layak". Hasil perhitungan untuk siswa ada pada Tabel 5 dengan rata-rata "Sangat Layak". Berikut adalah penjabarannya:

1. Validasi Ahli Media.

a. Uji Kelayakan dan Presentase Interprestasi.

Tabel 3. Hasil Perhitungan Rata-rata Angket Validasi Ahli Media.

\begin{tabular}{|l|c|c|c|c|}
\hline No & Aspek Penilaian & Skor & Presentase & Kualitas \\
\hline 1 & $\begin{array}{c}\text { Desain } \\
\text { Pembelajaran }\end{array}$ & 64 & $88 \%$ & Sangat Layak \\
\hline 2 & Komunikasi Visual & 47 & $83 \%$ & Sangat Layak \\
\hline 3 & Perangkat Lunak & 59 & $81 \%$ & Sangat layak \\
\hline Total & & $\mathbf{1 7 0}$ & $\mathbf{8 4 \%}$ & Sangat layak \\
\hline
\end{tabular}

b. Validitas Isi

$$
\text { Nilai rata }- \text { rata }=\frac{19,99}{25}=0,79
$$

Ketentuan pada item 25 di dalam tabel Aiken V adalah dengan lower limit 0,64 sampai upper limit 0,93 atau nilai $\mathrm{V}$ mencapai 0,83 . Hasil nilai rata-rata $\mathrm{V}=0,79$ dinyatakan valid [16]. 
2. Validasi Ahli Materi.

a. Uji Kelayakan dan Presentase Interprestasi.

Tabel 4. Hasil Perhitungan Angket Validasi Ahli Materi.

\begin{tabular}{|l|l|l|l|l|}
\hline No & Aspek Penilaian & Skor & Presentase & Kualitas \\
\hline 1 & Pembelajaran & 105 & $82,03 \%$ & Sangat Layak \\
\hline 2 & Komunikasi Visual & 45 & $80,35 \%$ & Layak \\
\hline 3 & Paikem & 33 & $82,5 \%$ & Sangat Layak \\
\hline Total & & $\mathbf{1 8 3}$ & $\mathbf{8 1 , 6 2 \%}$ & Sangat Layak \\
\hline
\end{tabular}

b. Uji Validasi

a. Uji Validasi Ahli Materi

$$
\text { Nilai rata }- \text { rata }=\frac{17,32}{23}=0,753
$$

Ketentuan pada item 23 di dalam tabel Aiken adalah dengan lower limit 0,74 sampai upper limit 0,98 atau nilai $\mathrm{V}$ mencapai 0,92 . Hasil nilai rata-rata $\mathrm{V}=0,753$ dinyatakan valid.

b. Uji Validasi PAIKEM Ahli Materi

$$
\text { Nilai rata }- \text { rata }=\frac{3,381}{5}=0,766
$$

Ketentuan pada item 5 di dalam tabel Aiken adalah dengan lower limit 0,6 sampai upper limit 0,91 atau nilai $\mathrm{V}$ mencapai 0,79 . Hasil nilai rata-rata $\mathrm{V}=0,766$ dinyatakan valid.

3. Validasi Siswa

a. Uji Kelayakan dan Presentase Interprestasi

Tabel 5. Hasil Perhitungan Angket Validasi Siswa.

\begin{tabular}{|c|c|c|c|c|}
\hline No & Aspek Penilaian & Skor & Presentase & Kualitas \\
\hline 1. & Umum & 90 & $90 \%$ & Sangat Layak \\
\hline 2. & Paikem & 83 & $83 \%$ & Sangat Layak \\
\hline \multicolumn{2}{|c|}{ Total } & $\mathbf{1 7 3}$ & $\mathbf{8 6 , 5 \%}$ & Sangat Layak \\
\hline
\end{tabular}

b. Uji Validasi

a. Uji Validasi Siswa

$$
\text { Nilai rata }- \text { rata }=\frac{4,31}{5}=0,86
$$

Ketentuan pada item 5 di dalam tabel Aiken adalah dengan lower limit 0,6 sampai upper limit 0,91 atau nilai $\mathrm{V}$ mencapai 0,79 . Hasil nilai rata-rata $\mathrm{V}=0,86$ dinyatakan valid.

b. Uji Validasi PAIKEM Siswa

$$
\text { Nilai rata }- \text { rata }=\frac{3,85}{5}=0,77
$$

Ketentuan pada item 5 di dalam tabel aiken adalah dengan lower limit 0,6 sampai upper limit 0,91 atau nilai $\mathrm{v}$ mencapai 0,79 . Hasil nilai rata-rata $v=0,77$ dinyatakan valid. 


\section{KESIMPULAN}

Aplikasi media pembelajaran ini dikembangkan menggunakan software Articulate Storyline 3 dan di export menjadi aplikasi Android yang mengangkat mata pelajaran Ilmu Pengetahuan Alam dengan materi Jaringan Tumbuhan. Dalam media ini terdapat materi, quiz, dan video pembelajaran tentang materi yang akan dipelajari siswa dengan menerapkan pendekatan PAIKEM pada setiap elemen-elemen desain aplikasi ini. Kemudian dilakukan pengujian Blackbox yang hasilnya semua skenario pengujian berfungsi normal. Penelitian ini mengikuti 3 tahapan awal model pengembangan ADDIE (Analyze, Design, Development, Implementation, Evaluation).

Berdasarkan perhitungan angket yang diberikan kepada ahli materi, ahli media dan siswa media pembelajaran ini dikategorikan Layak dengan rincian sebagai berikut : (1). Penilaian ahli materi mendapatkan nilai rata-rata dengan presentase $81,62 \%$ pada kategori sangat layak. Pada hasil rata-rata koefisien V ahli materi ini dijadikan dua penilaian karena untuk memvalidasi penerapan strategi PAIKEM dengan nilai sebesar 0,753 dan 0,766 yang dinyatakan valid. (2) Penilaian ahli media mendapatkan nilai rata-rata dengan presentase $84 \%$ pada kategori sangat layak. Pada koefisien V sebesar 0,79 yang dinyatakan valid. (3) Penilaian kelayakan siswa mendapatkan nilai rata-rata dengan presentase $86,5 \%$ pada kategori sangat layak. Dari perhitungan koefisien V siswa untuk aspek umum dan aspek untuk memvalidasi penerapan strategi PAIKEM dalam media didapati nilai sebesar 0,86 dan 0,77 yang dinyatakan valid.

\section{DAFTAR PUSTAKA}

[1] A. Salim, M. Masykuri, and Maridi, "Pengembangan Pembelajaran Ipa Berbasis Paikem Dengan Model Discovery Learning Untuk Meningkatkan Aktivitas Belajar IPA,” Pros. Semin. Nas. Pendidik. Sains, vol. 21, pp. 33-39, 2017, [Online]. Available: https://jurnal.fkip.uns.ac.id/index.php/snps/article/view/11368.

[2] B. Warsita, "Strategi Pembelajaran Dan Implikasinya Pada Peningkatan Efektivitas Pembelajaran," J. Teknodik, vol. XIII, no. 1, pp. 064-076, 2018, doi: 10.32550/teknodik.v13i1.440.

[3] F. Fatimah and R. D. Kartikasari, "Strategi Belajar Dan Pembelajaran Dalam Meningkatkan Keterampilan Bahasa," Pena Literasi, vol. 1, no. 2, p. 108, 2018, doi: 10.24853/pl.1.2.108-113.

[4] E. Mulyatiningsih, "Paikem (Pembelajaran Aktif, Kreatif Inovatif, Efektif, Dan Menyenangkan)", p. 30, 2010, [Online]. Available: http://staffnew.uny.ac.id/upload/131808329/pengabdian/5cmodel-pembelajaran-paikem22810.pdf.

[5] S. Nurdin, "Penerapan Pendekatan PAKEM dalam Pembelajaran IPA di MIN Rukoh," PIONIR J. Pendidik., vol. 4, no. 2, pp. 1-11, 2015.

[6] Samriah, "Penerapan Pendekatan Paikem Untuk Meningkatkan Hasil Belajar Siswa Pada Pokok Bahasan Energi dan Kegunaanya di Kelas IV SDN 4 Kamalu Tolitoli,” J. Kreat. Tadulako, vol. 4, no. 11, pp. 97-108, 2000.

[7] M. Churiyah, "Mobile Learning Application Berbasis Android : Peran Guru Dalam Pembelajaran Peserta Didik Gen Z \& Alfa," Graha Pengabdi., vol. Vol. 2 No., 2020.

[8] C. Peterson, "Bringing ADDIE to life: instructional design at its best - learning \& technology library (LearnTechLib)," J. Educ. Multimed. Hypermedia, vol. 12, no. 3, pp. 227-241, 2003, [Online]. Available: http://www.learntechlib.org/p/2074/.

[9] Juannita and B. P. Adhi, "Pengembangan Media Pembelajaran Sistem Pencernaan Manusia Untuk Kelas 8 SMP dengan Fitur Augmented Reality Berbasis Android (Studi Kasus : SMPN 7 Depok)," J. Pinter, vol. 1, no. 1, pp. 76-81, 2017, [Online]. Available: http://journal.unj.ac.id/unj/index.php/pinter/article/download/1894/2369.

[10] N. Parsazadeh, R. Ali, and M. Rezaei, "A framework for cooperative and interactive mobile learning to improve online information evaluation skills," Comput. Educ., vol. 120, no. May, pp. 75-89, 2018, doi: 10.1016/j.compedu.2018.01.010.

[11] A. U. Berliana, "Pengembangan Media Pembelajaran Berbasis Android melalui Model Pembelajaran PAIKEM (Pembelajaran Aktif, Inovatif, Kreatif, dan Menyenangkan)," J. Instr. Dev. Res., vol. 2, no. 2, pp. 57-68, 2021.

[12] U. Hanifah, "PENERAPAN MODEL PAIKEM Dengan MENGGUNAKAN MEDIA PERMAINAN BAHASA Dalam PEMBELAJARAN BAHASA ARAB,” Ilmu Tarb. “At-Tajdid,” pp. 301-330, 2016.

[13] I. Indrayati, "Implementasi Paikem Pengaruhnya Terhadap Kompetensi, Kualitas, Efisiensi Dan Efektivitas Pembelajaran," Media Mahard., vol. 17, no. 2, p. 312, 2019, doi: 10.29062/mahardika.v17i2.86.

[14] T. S. Jaya, "Pengujian Aplikasi Dengan Metode Blackbox Testing Boundary Value Analysis (Studi Kasus: Kantor Digital Politeknik Negeri Lampung)," J. Inform. J. Pengemb. IT, vol. 3, no. 2, pp. 45-48, 2018.

[15] R. S. Wahono, “Aspek dan Kriteria Penilaian Media Pembelajaran | RomiSatriaWahono.Net,” 2006. https://romisatriawahono.net/2006/06/21/aspek-dan-kriteria-penilaian-media-pembelajaran/ (accessed Nov. 24, 2021).

[16] Lewis. R. Aiken, "Three Coefficients For Analyzing The Reliability And Validity Of Ratings," Educ. Psychol. Meas., vol. 45, pp. 131-141, 1985.

\section{Biodata Penulis}

Ryan Rizki Adhisa, memperoleh gelar Sarjana Komputer (S.Kom.), Program Studi Teknik Informatika Universitas Brawijaya (UB), lulus tahun 2015. Tahun 2019 memperoleh gelar Magister Komputer (M.Kom) dari Program Studi Magister Teknik Informatika Institut Teknologi Sepuluh Nopember (ITS). Saat ini sebagai Staf Pengajar pada Program Studi Pendidikan Teknik Informatika Universitas Muhammadiyah Surakarta (UMS). Bidang keilmuan yang didalami adalah Jaringan Komputer dan Pengembangan Media Pembelajaran Berbasis TI. 
Vol 5 No.2 Edisi 2021

Dias Aziz Pramudita, memperoleh gelar Sarjana Komputer (S.Pd.) pada tahun 2015 dari Program Studi Pendidikan Teknik Informatika Universitas Negeri Yogyakarta (UNY). Pada tahun 2018 memperoleh gelar Magister of Computer Science (M.Cs) dari Program Studi Magister Ilmu Komputer Universitas Gadjah Mada (UGM). Saat ini sebagai Staf Pengajar pada Program Studi Pendidikan Teknik Informatika Universitas Muhammadiyah Surakarta (UMS).

Eric Santoso, adalah mahasiswa Program Studi Pendidikan Teknik Informatika Universitas Muhammadiyah Surakarta (UMS) angkatan tahun 2016. 